\title{
Anti-EGFRvIll Antibody Drug Conjugate AMG 595
}

National Cancer Institute

\section{Source}

National Cancer Institute. Anti-EGFRvIII Antibody Drug Conjugate AMG 595. NCI

Thesaurus. Code C99222.

An immunoconjug ate consisting of a human monoclonal antibody directed against the deletion-mutant of epidermal growth factor receptor, EGFRvIII, conjug ated via a noncleavable linker to the cytotoxic agent maytansinoid DM1, with potential antineoplastic activity. The monoclonal antibody moiety of this immunoconjug ate binds to EGFRvIII on tumor cell surfaces. After internalization, the DM1 moiety binds to tubulin, thereby disrupting microtubule assembly/disassembly dynamics and inhibiting cell division and the proliferation of cancer cells that express the EGFRvIII mutant. EGFRvIII, a deletion mutation of exons 2-7 in the epidermal growth factor receptor gene, is overexpressed by a variety of cancers, including g lioblastoma multiforme, non-small lung carcinoma, and breast carcinoma. 